\title{
Measuring Intra-Canal Fluid Temperature Elevation and Ultrastructural Changes of Root Canal Surface During Irradiating With 940 Nm Diode Laser in Endodontic Treatment \\ Sheima'a A. Al-Zand
}

Institute of Laser for Postgraduate Studies, University of Baghdad Ali S. Mahmood

Institute of Laser for Postgraduate Studies, University of Baghdad

Tamara Al-Karadaghy

Institute of Laser for Postgraduate Studies, University of Baghdad

Mohammed Al-Maliky

Institute of Laser for Postgraduate Studies, University of Baghdad

\begin{abstract}
Objective: The purpose of this study was to observe the temperature elevation and evaluate the duration of its decreasing from root canal irrigant, as well as to observe smear layer removal ability of root canal surface when using of $940 \mathrm{~nm}$ diode laser as assistant in root canal sterilization.

Background: laser irradiation may cause a thermal injury to the root structure and the surrounding periodontal tissues. Diode laser is weakly absorbed by water and tooth hard structure so it does not remove smear layer. Combination of chemical irrigants with diode laser irradiation in endodontics has superior results in removing the smear layer.

Materials and methods: For this study, a total of 32 sound single rooted extracted human teeth were used. Twenty of them were randomly divided into two groups $(n=10)$ : Group A irradiated with $1.5 \mathrm{~W} \mathrm{CW}$ of $940 \mathrm{~nm}$ diode laser for total irradiation time of 20 s, Group B irradiated with $2.5 \mathrm{~W}$ in Pulsed mode with frequency of $20 \mathrm{~Hz}$ for the same duration. K-type thermocouple was used to record temperature of fluid inside the canal during the rest period of lasing cycle at cervical portion of the root. Twelve teeth were divided into 6 groups ( $a, b, c, d, e$, and f), two per group, where used for scanning electron microscope (SEM) characterization of root canal surface. These teeth were treated with different chemical irrigants and different laser powers. Then, longitudinally sectioned and prepared for imaging.

Results: temperature elevation in both groups was acceptable with no significant difference between them $(P>0.01)$, the SEM showed increased smear layer removal ability during combination of chemical irrigants with diode laser.

Conclusion: both laser powers were safe to be used as assistant in root canal sterilization as the temperature of fluid decrease quickly within $2 \mathrm{~s}$, and the SEM images showed that the best results were achieved during combination of chemical irrigants with laser.
\end{abstract}

KEYWORDS

$940 \mathrm{~nm}$ diode laser, endodontics, smear layer

$$
\begin{aligned}
& \text { قياس ارتفاع حرارة السائل داخل القناة وكشف الصورة فائقة التركيبية للتغيرات الحاصلة على سطح القناة اثناء } \\
& \text { تشعيعه بليزر الدايود ذو الطول الموجي } 940 \text { نانومتر اثناء حشوة الجذر. } \\
& \text { شيماء علي الزند } \\
& \text { أ. م. م. د. علي شكر محمود }
\end{aligned}
$$

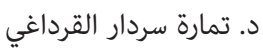

$$
\begin{aligned}
& \text { م.م. محمد عبود المالكي } \\
& \text { معهد الليزر للار اسات العليا/ جأمعة بغداد المالي }
\end{aligned}
$$

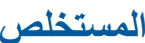

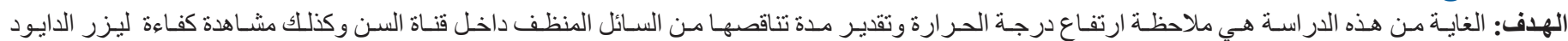

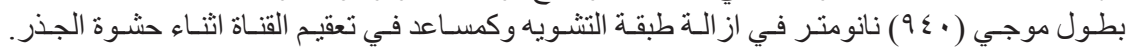

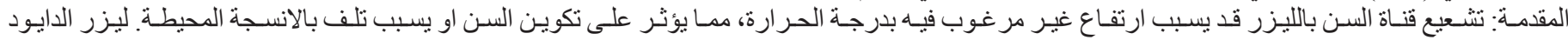

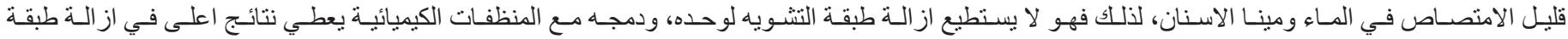
التشـويه.

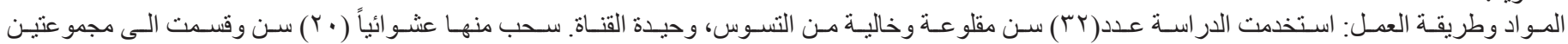

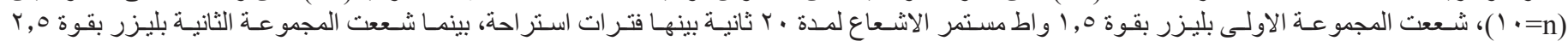

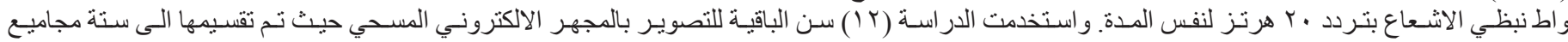

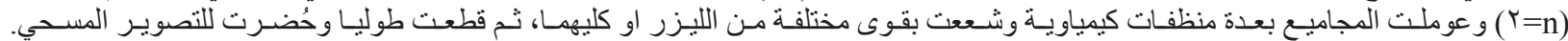

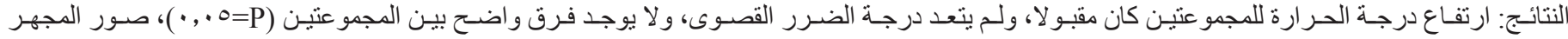

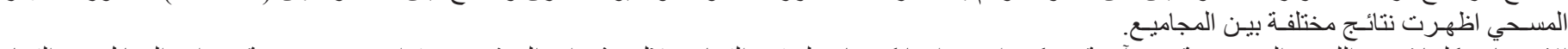

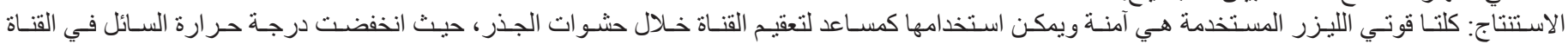

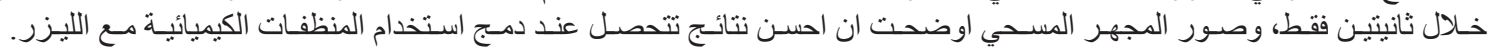

\section{INTRODUCTION}

The complexity of the root canal anatomy and the difficulty to clean and disinfect the 3-D endodontic space encouraged the invention and development of new methods to sterilize this system ${ }^{(1)}$.

Almost all the available laser wavelengths were 
used in endodontic experiments, ranging from visible to far infrared lasers, as antibacterial due to their thermal effect that destroy the microorganisms ${ }^{(2)}$.

Some lasers are found to cause alteration on the root canal surface and others penetrate the depth of the hard tissue with no harm causing increase in temperature ${ }^{(3)}$.

Dental Diode lasers are known of their low affinity to water and Hydroxyapatite of hard dental tissue. Therefore, it pass along the dentinal tubules without causing any damage to tooth structure and can reach the bacteria that lay down in deeper dentin layers $^{(4)}$.

Lasers have many positive outcomes, but its thermal effect may cause some damage to dentine walls if not properly controlled. Near infrared lasers produce undesired thermal effect and morphological changes on dentin walls if they were used on dry canal or bloody canals since diode lasers have high affinity to Hemoglobin Still these lasers cannot remove the smear layer effectively ${ }^{(5)}$, but can increase the efficiency of some chemical irrigants as laser increases the temperature of the fluid inside the canal or by causing cavitation effect ${ }^{(6)}$. Hmud etal verified the safety of using high power diode lasers to raise the temperature of intracanal irrigants over $30^{\circ} \mathrm{C}$ with only a maximum of $4{ }^{\circ} \mathrm{C}$ on external root surface ${ }^{(7)}$.

NIR lasers has direct irradiation technology in endodontic sterilization usually termed as laser assisted root canal treatment, it targets the bacterial pigments by photothermal interaction ${ }^{(8)}$. According to many studies the power of the used lasers should not overcome $5 \mathrm{~W}$ of continuous irradiation for more than $20 \mathrm{~s}$. and if any more irradiation is desired, then a rest periods should be considered between doses ${ }^{(7,9-11)}$.

Eriksson and Albrektsson described the increase in temperature to $47{ }^{\circ} \mathrm{C}$ to be unsafe for periapical structure $^{(10)}$. Accordingly, both Gutknecht et al. and Machida et al. ${ }^{(12,13)}$ stated that to avoid damage to bone or periodontal ligaments around the tooth, the temperature of root surface should not overcome $7{ }^{\circ} \mathrm{C}$ during lasing. The effect of laser on tooth is influenced by the wavelength, power density, irradiation mode, duration of exposure, and tissue type ${ }^{(14)}$. The conduction of heat to the tissue surround the tooth is also affected by the presence of air or water during irradiation. The apical constriction and the narrow dentin thickness in apical region is the most hazardous to thermal elevation ${ }^{(15)}$.

The use of chemical irrigants during endodontic treatment has many advantages like lubrication of the canal during instrumentation, bactericidal effect and dissolution of smear layer contents. The most effective irrigants used are $\mathrm{NaOCl}$ and EDTA ${ }^{(16)(17)}$.

The aim of this in vitro study was to assess the temperature changes of the fluid inside canal in the chamber portion of the root canal and the duration of its decreasing after laser irradiation with the selected parameters, and, to investigate the ultrastructural changes on the root internal surface at the cervical portion.

\section{MATERIALS AND METHODS}

The used laser is the Epic ${ }^{\mathrm{TM}} 10$ Diode laser (940 nm wavelength; Biolase Technology, Irvine, CA, USA). Laser delivery was via bar end firing tip of $200 \mu \mathrm{m}$ diameter and $14 \mathrm{~mm}$ length.

A total of 32 single canal central incisors, canines, and premolars were collected at the Ministry of Health, Iraq. Twenty centrals and canines were selected for temperature measurement experiment due to their large pulp chamber. They were divided randomly into two groups $A$ and $B$ with $(n=10)$ for each. The rest twelve premolars where used for (SEM) imaging. All the roots outer surfaces were cleaned and scaled then sectioned horizontally using slow speed disc bur with continuous irrigation to $14 \mathrm{~mm}$ length to allow a direct access to the canal. Preparation of canals was done using Protaper Universal system to size $\mathrm{AF} 4$, then the chambers of the roots were widened with Gates Glidden \#2 to facilitate the entrance of the thermocouple for the temperature measurement.

The used powers were as follows:

- Group A (GA): $1.5 \mathrm{~W}$ in continuous wave $(\mathrm{CW})$ mode

- Group B (GB): 2.5 W in Pulsed mode with $20 \mathrm{~Hz}$ frequency and $20 \mathrm{~ms}$ pulse duration.

The choosing of lasing modes were selected $\mathrm{CW}$ in the minimum power that proved to cause bactericidal action which is $1.5 \mathrm{~W}$, while with higher powers $2.5 \mathrm{~W}$, the mode was converted to pulsed so that a shutting action of laser beam would permit less temperature spread over the region.

The lasing protocol was to irradiate each sample for $5 \mathrm{sec}$ in 4 cycles with $10 \mathrm{~s}$ of rest period between each cycle, so the total irradiation time would be 20 $\mathrm{s}$ and total work time was $50 \mathrm{~s}$. The tip of the laser system was fixed $2 \mathrm{~mm}$ from the apex $(1 \mathrm{~mm}$ from the preparation) and moved coronally in a helicoid motion in a rate of about $2 \mathrm{~mm} \backslash \mathrm{sec}$.

\section{Temperature measurements of fluid inside the canal:}

Each sample was fixed in a holder from its 
coronal portion and the canal filled with distilled water (DW). The experiment was held in a room temperature $21^{\circ} \mathrm{C} \pm 1{ }^{\circ} \mathrm{C}$. The temperature was measured using k-type thermocouple (Head diameter $=0.8 \mathrm{~mm}$ and Basic Accuracy $=0.1 \%$ ) that is connected to thermometer (AMPROBE TMD ${ }^{\circledR}-56$, Everett, WA, USA) and PC to collect the data every $1 \mathrm{~s}$. the thermocouple head measured the temperature of the fluid inside the canal by inserting its tip in pulp chamber during the rest period of irradiation and for 3 times for each sample (as the irradiation cycle has 3 resting periods).

The experiment was held on the dental clinics of the Laser Institute for Post Graduate studies/ Baghdad University, Iraq.

\section{Scanning Electron Microscope (SEM)}

Effects of Different laser powers with different irrigants on root canal surface were compared with control group using SEM. Twelve samples of premolar teeth were used and divided randomly into 6 groups $(n=2)$. These samples were treated according to the following protocols:

Group (a): control group. preparation with Protaper Universal system and irrigated with normal saline, then followed by $2.5 \mathrm{ml}$ of $3 \% \mathrm{NaOCl}$ for 120 s. then irrigated finally with $10 \mathrm{ml}$ of distilled water.

Group (b): preparation with protapered system and irrigated with normal saline, then followed by 2.5 $\mathrm{ml}$ of EDTA for $120 \mathrm{sec}$, then $2.5 \mathrm{ml}$ of $3 \% \mathrm{NaOCl}$ for $120 \mathrm{~s}$.

Group (c) preparation with protapered system and irrigated with normal saline, then followed by laser irradiation with $1.5 \mathrm{~W} \mathrm{CW}$ mode while saline inside canal. The same lasing protocol is used.

Group (d) preparation with protapered system and irrigated with normal saline, then followed by laser irradiation with $2.5 \mathrm{~W}$ pulsed mode while saline inside canal. The same lasing protocol is used.

Group (e) preparation with protapered system and irrigated with normal saline, then followed by laser irradiation with $1.5 \mathrm{~W} \mathrm{CW}$ mode while $2.5 \mathrm{ml}$ of EDTA inside canal for $120 \mathrm{~s}$. followed by $2.5 \mathrm{ml}$ of $3 \% \mathrm{NaOCl}$ for $120 \mathrm{sec}$. The same lasing protocol

Table 1: descriptive statistics for the experiment of measuring the temperature changes inside the canal

18

is used.

Group (f) preparation with protapered system and irrigated with normal saline, then followed by laser irradiation with $2.5 \mathrm{~W}$ pulsed mode while $2.5 \mathrm{ml}$ of EDTA inside canal for $120 \mathrm{~s}$. followed by $2.5 \mathrm{ml}$ of $3 \% \mathrm{NaOCl}$ for $120 \mathrm{sec}$. The same lasing protocol is used.

All samples of SEM imaging were sectioned in two halves by making grooves along the buccal and palatal surface of the root without penetrating into the canal to avoid canal surface contamination by smear layer, then, a bi-tapered chisel and surgical hammer were used to crack the tooth in two halves through the grooves. Then, the samples were placed in eppendorf tube, later the samples passed through fixation and dehydration processes with graded Ethanol series (25, $50,75,95$, and $100 \%$ )

The SEM imaging was done at Science College/ Al-Nahrain University. The system is Inspect S50 (FEI, USA). Multi images were taken at magnification $(1500 \mathrm{X})$ at $11 \mathrm{~mm}$ from the apex, representing the cervical portion.

\section{Data Analysis:}

All data were analyzed for normality and independent t- test was used for comparisons. Data were normally distributed for the two groups. $P$ Values $<0.01$ were considered statistically significant. Analyses were performed using the SPSS software V.20.0 (IBM Corp., Armonk, NY, USA).

\section{RESULTS \\ Fluid temperature inside canal}

The maximum $\Delta \mathrm{T}$ measures for GA was $6.70^{\circ} \mathrm{C}$ and the minimum was $1.30^{\circ} \mathrm{C}$ and the mean was 3.19 ${ }^{\circ} \mathrm{C}$, while for $\mathrm{GB}$ the maximum $\Delta \mathrm{T}$ was $7.30^{\circ} \mathrm{C}$ and the minimum was $1.70{ }^{\circ} \mathrm{C}$ and the mean was $4.78^{\circ} \mathrm{C}$ as shown in Table 1 . The means of $\Delta \mathrm{T}$ for all samples were measured in every second and plotted in a chart, which shows the change in temperature according to lasing protocol (Error! Reference source not found.). This chart shows that temperature measured at $2 \mathrm{~s}$ after irradiation cycle stops.

\begin{tabular}{|c|c|c|c|c|c|c|}
\hline Groups & $\boldsymbol{N}$ & $\begin{array}{c}\text { Mini- } \\
\text { mum }\end{array}$ & Maximum & Mean & $\begin{array}{c}\text { Std. } \\
\text { Error }\end{array}$ & Std. Deviation \\
\hline G A & 10 & 1.30 & 6.70 & 3.19 & 0.47806 & 1.512 \\
\hline G B & 10 & 1.70 & 7.30 & 4.78 & 0.61856 & 1.956 \\
\hline
\end{tabular}


difference between the two groups with $\mathrm{P}$ value (0.057) as shown in Table 2.

Table 2: Independent t-test for temperature of fluid inside canals groups

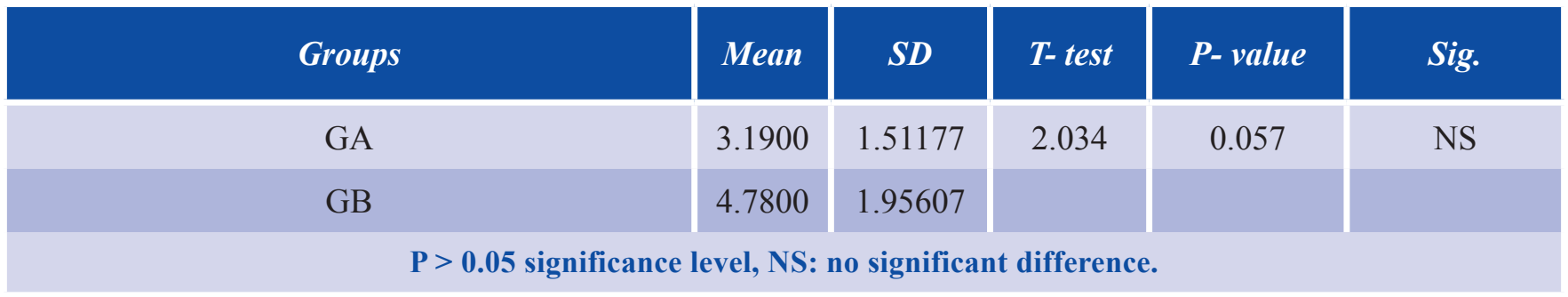

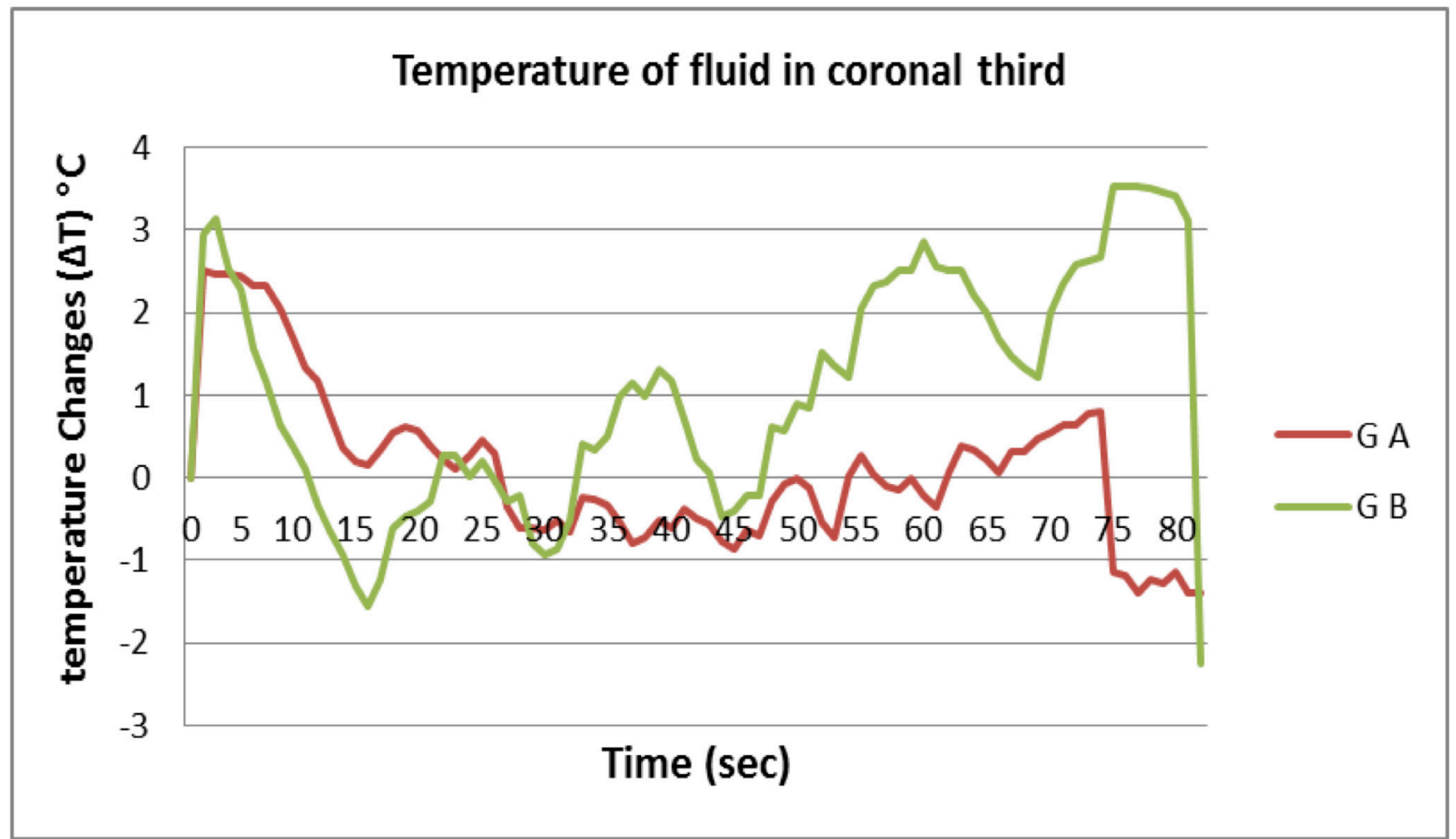

Figure 1: means of temperature changes with time, using thermocouple for measuring the coronal fluid temperature in resting period during laser cycles $G A(1.5 \mathrm{~W} C W$ mode) and $G B(2.5 \mathrm{~W}$ in pulsed mode).

\section{SEM micrographs:}

One micrpgraph from one hemisection of each group was taken for the cervical third of the root with two magnification powers as shown in Figure 2

The control group (a) showed a heavy cover of smear layer and debris, and only small numbers of dentinal tubules are opened 2.A. While in (b), the effect of EDTA was very obvious in washing the smear layer and cleaning the surface from debris 2.B. In Group (c), the use of laser with distilled water in canal - no chemical irrigants used- also showed a cover of smear layer and debris, a shape of globules appear in image due to smear layer melting by the heat of irradiation. 2.C.

In group (d), a higher power of laser was used, and caused melting of the smear layer, appear as clusters or globules. This melting allowed some dentinal tubules to be clean and opened, but not in the entire surface. 2.D.

The last two groups (e) and (f) showed the superior results with clean surface and opened dentinal tubules. The high power of laser seems to cause no harm to the tooth internal structure, since no signs of cracking or carbonization appeared in images. 2. E, F. 


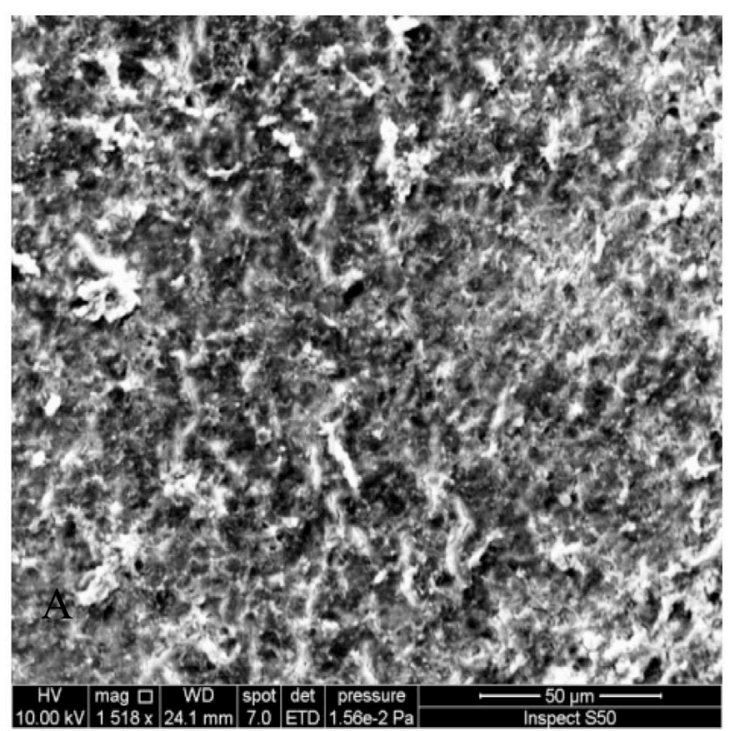

A

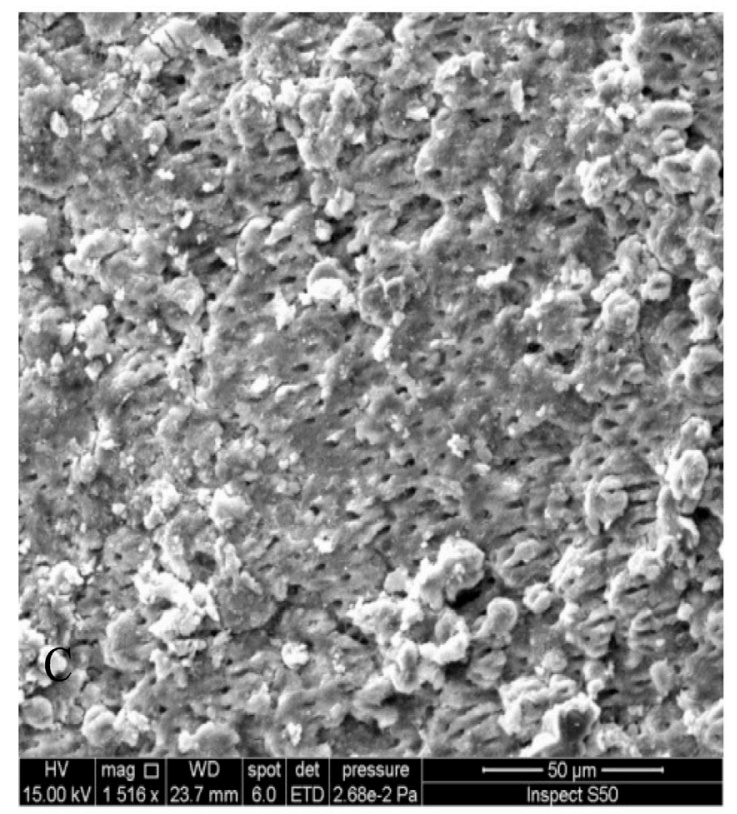

C

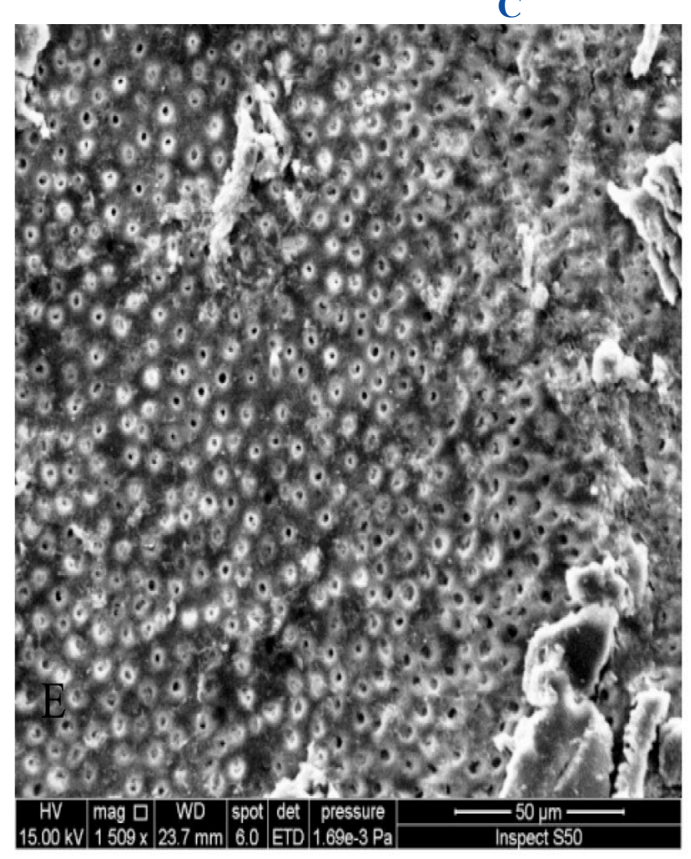

E

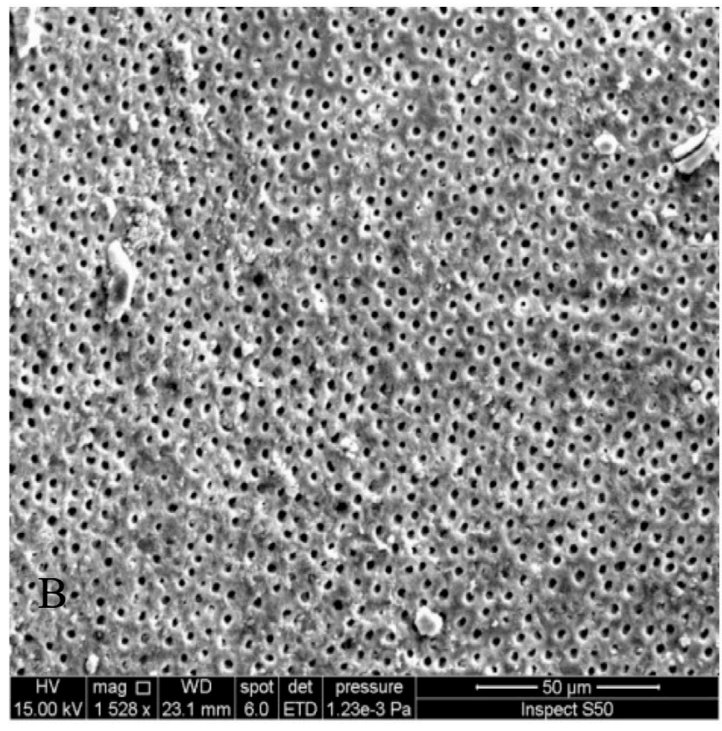

B

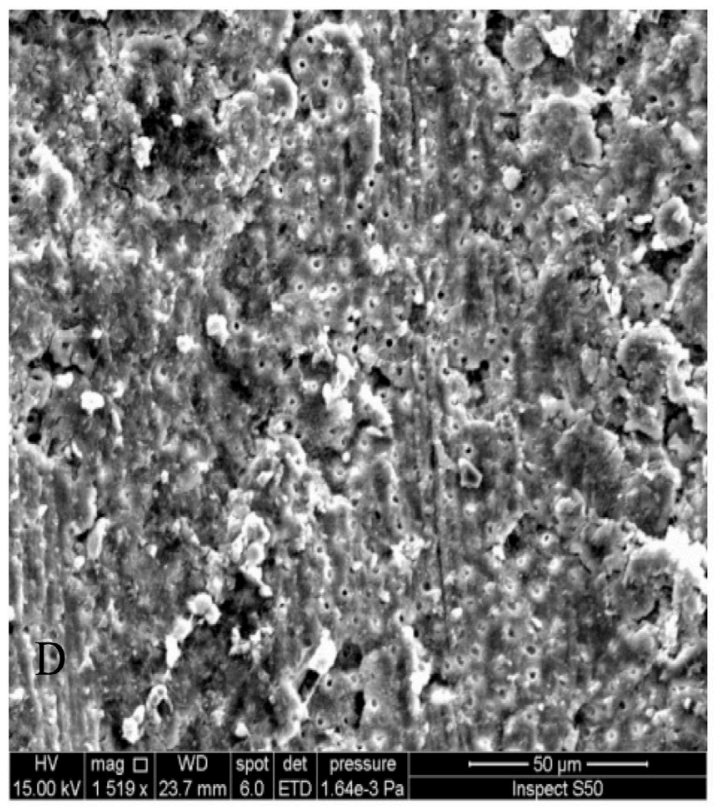

D

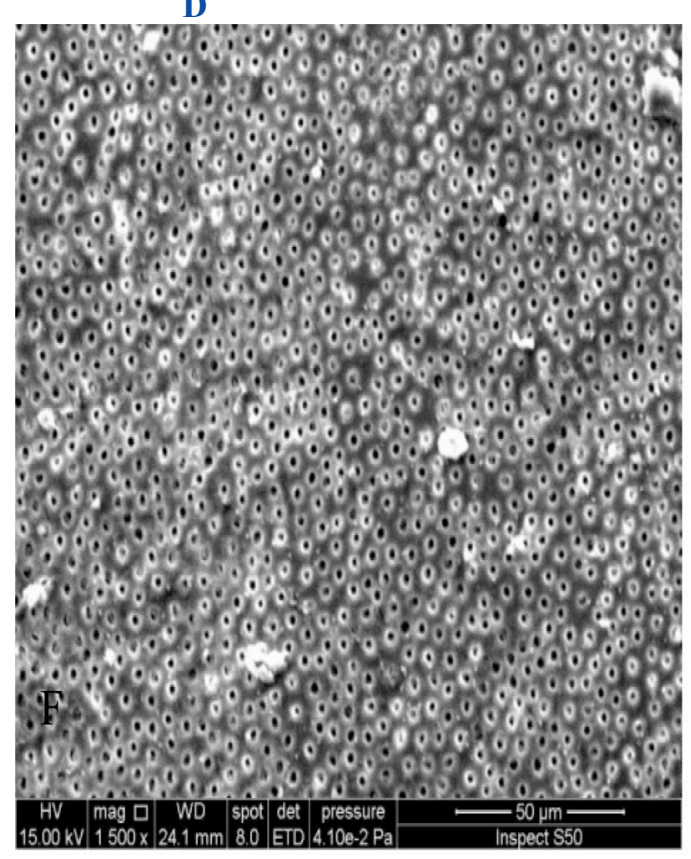

F

Figure 2: SEM images of Cervical portion with (1500X), A- group a (control) B-group b ( EDTA + NaOCl) C- group c (laser 1.5 W) D- group d (laser 2.5 W) E- group e (laser $1.5 \mathrm{~W}+$ EDTA) F- group f (laser 2.5 W+ EDTA) 


\section{DISCUSSION}

Evaluating the thermal elevation inside the root canal is important to ensure that the used laser protocol is safe for tooth structure and for the surrounding bone and periodontal ligaments as well.

This study showed that using the $940 \mathrm{~nm}$ diode laser in powers of (1.5 W CW mode) and (2.5 W in pulsed mode) did not cause prolonged elevation in temperature, and the decrease of fluid temperature after lasing cycle was fast, it needs less than $2 \mathrm{~s}$ to decrease from over $30{ }^{\circ} \mathrm{C}$ to about $7{ }^{\circ} \mathrm{C}(7)$. This is done by measuring the temperature of fluid inside the coronal part where only a modest increase in temperature appeared with no significant difference between the two groups. This is may be due to the irradiation of laser is directed forward toward the apical portion so most temperature is focused there, especially when using an end firing tip, and this matched the results of Hmud et al (7).

The used wavelength with the used powers was proved to have adequate bactericidal role, and it can be used for disinfection of root canal. Its use eliminated the E. coli and E. faecalis colonies from the dentin surface ${ }^{(4)}$.

In this study, thermocouples were used to evaluate the solution temperature inside the canal because the measuring is indirect or noncontact temperature. The presence of solution inside the canal during lasing and the resting time between laser cycles helped the tooth to cool to baseline temperature in a matter of seconds. Also the cooling time can be reduced by flushing the tooth with saline after the laser cycle ${ }^{(5)}$.

A previous study measured the temperature in conditions of room temperature, ignoring the effect of tissue surrounding the tooth and blood circulation in periodontal ligament and bone, but if these effects were considered, it's thought that temperature will be less since the blood circulation work as cooling system to the area ${ }^{(18)}$.

This study also evaluated the effect of using different chemical irrigants with and without the laser in coronal portion. The SEM images showed a similar effect on root surface when using EDTA and $\mathrm{NaOCl}$ irrigants alone and when they are used with laser irradiation. The superiority of laser groups as disinfectants cannot be neglected due to its essential bacteriocidal role in deep layers of the dentinal tubules ${ }^{(19)}$. Also, the combination of both irrigants with laser irradiation showed synergistic effect and intensified the antibacterial action ${ }^{(20)}$.

The results of our SEM imaging come in along with Alfredo work ${ }^{(21)}$, and also with Saraswathi ${ }^{(22)}$. In
SEM images, the control group where roots treated with $\mathrm{NaOCl}$ alone, the least number of dentinal tubules was opened and the surface was covered with smear layer, since the $\mathrm{NaOCl}$ has the ability to remove only the organic material of smear layer and has limited bactericidal action on the surface ${ }^{(23)(24)}$.

In case of combining the effect of EDTA with $\mathrm{NaOCl}$, the result is total removal of smear layer as EDTA dissolve the inorganic component of the smear layer, and they both wash the root surface adequately. (17)

In the (e and f) groups of SEM, the laser was used alone with no chemical irrigants. The laser is supposed to cause cleaning of the walls due to cavitational effect of aqueous irrigant by laser according to Hmud study (6) , but this did not appear clear and it has week effect may be due to the large area of the pulp chamber. On the other hand, the temperature increase due to lasing caused melting and fusion of the smear layer, which appeared as globules in the images, and this caused opening of the dentinal tubules. This appeared more obvious when laser power increased. Both laser powers did not cause any crack or fissure on the root surface.

In the case of combining the effect of chemicals with laser, the results should be better in removing the smear layer and in disinfecting the root canal system. The white shadow appeared around each opened tubule was due to melting of inorganic dentinal structure on the tubule orifice because the irradiation at higher laser powers result in melting of peri and intra tubular dentin, and cause to decrease its diameter ${ }^{(21)}$. So to avoid this, the study recommends using EDTA and $\mathrm{NaOCl}$ before lasing protocol.

\section{CONCLUSIONS}

Within the limitation of this study, we concluded that using $940 \mathrm{~nm}$ diode laser irradiation for disinfecting the root canal system is totally safe with the used powers since temperature of irrigant reduced from $30{ }^{\circ} \mathrm{C}$ to $7{ }^{\circ} \mathrm{C}$ or less in about $2 \mathrm{~s}$, and it gives better results in smear layer removal when used with $\mathrm{NaOCl}$ and EDTA irrigants.

\section{REFERENCES}

1. Olivi G, Crippa R, Iaria G, Kaitsas V, DiVito E, Benedicenti S. Lasers in endodontics ( Part I). Roots. 2011;1:6-9.

2. Schoop U, Kluger W, Dervisbegovic S, Goharkhay K, Wernisch J, Georgopoulos A, et al. Innovative wavelengths in endodontic treatment. Lasers in surgery and medicine. 2006;38(6):624-30.

3. MoritzA.OralLaserApplication.Berlin:QuintessenceVerlags$\mathrm{GmbH} ; 2006$.

4. Schoop U, Kluger W, Moritz A, Nedjelik N, Georgopoulos 
A, Sperr W. Bactericidal effect of different laser systems in the deep layers of dentin. Lasers in surgery and medicine. 2004;35(2):111-6.

5. da Costa Ribeiro A, Nogueira GE, Antoniazzi JH, Moritz A, Zezell DM. Effects of Diode Laser $(810 \mathrm{~nm})$ Irradiation on Root Canal Walls: Thermographic and Morphological Studies. Journal of endodontics. 2007;33(3):252-5.

6. Hmud R, Kahler WA, George R, Walsh LJ. Cavitational effects in aqueous endodontic irrigants generated by nearinfrared lasers. Journal of Endodontics. 2010;36(2):275-8.

7. Hmud R, William A. Kahler, J. Walsh. Temperature Changes Accompanying Near Infrared Diode Laser Endodontic Treatment of Wet Canals. JOE. 2010;36(5):908-11.

8. Giovanni Olivi. Laser Use in Endodontics: Evolution from Direct Laser Irradiation to Laser-Activated Irrigation. J laser dentistry. 2013;21(2):58-71.

9. Uzunov Ts, Popova E, Grozdanova R, Uzunov T. THERMAL CHANGES IN THE HARD DENTALTISSUE AT DIODE LASER ROOT CANAL TREATMENT. Acta Medica Bulgarica. 2014;XLI(2):31-5.

10. Eriksson A. R, Albrektsson T. Temperature threshold levels for heat-induced bone tissue injury: a vital-microscopic study in the rabbit. The Journal of Prosthetic Dentistry. 1983;50(1):101-7.

11. Alfredo E, MA Marchesan, MD Sousa-Neto, A BrugneraJunior, YTC Silva-Sousa. Temperature variation at the external root surface during 980-nm diode laser irradiation in the root canal. Journal of dentistry. 2008;36(7):529-34.

12. Gutknecht N, Kaiser F, Hassan A, Lampert F. Long-term clinical evaluation of endodontically treated teeth by Nd:YAG lasers. Journal of clinical laser medicine \& surgery. $\quad$ 1996;14(1):7-11.

13. Machida T, Wilder-Smith P, Arrastia AM, Liaw LH, Berns MW. Root canal preparation using the second harmonic KTP:YAG laser: a thermographic and scanning electron microscopic study. Journal of Endodontics. 1995;21(8):8891.

14. Moritz A, Gutknecht N, Goharkhay K, Schoop U, Wernisch J, Sperr W. In vitro irradiation of infected root canals with a diode laser: results of microbiologic, infrared spectrometric, and stain penetration examinations. Quintessence International 1997;28(3):205-9.
15. George R, Walsh LJ. Thermal effects from modified endodontic laser tips used in the apical third of root canals with erbium-doped yttrium aluminium garnet and erbium, chromium-doped yttrium scandium gallium garnet lasers. Photomedicine and laser surgery. 2010;28(2):161-5.

16. Takeda FH, Harashima T, Kimura Y, Matsumoto K. A comparative study of the removal of smear layer by three endodontic irrigants and two types of laser. International Endodontic Journal. 1999;32(1):32-9.

17. Teixeira CS, Felippe MCS, Felippe WT. The effect of application time of EDTA and $\mathrm{NaOCl}$ on intracanal smear layer removal: an SEM analysis. International endodontic journal. 2005;38(5):285-90.

18. Karnik R, Pradhan S. Temperature Rise on External Root Surface during Laser Endodontic Therapy using $940 \mathrm{~nm}$ Diode Laser: An in vitro Study. international journal of laser dentistry. 2011;1(1):29-35.

19. Preethee T, Kandaswamy D, Arathi G, Hannah R. Bactericidal effect of the $908 \mathrm{~nm}$ diode laser on Enterococcus faecalis in infected root canals Journal of Conservative Dentistry. 2012 15(1):46-50.

20. Castelo-Baz P, Bahillo J, Seoane-Prado R, Gude F, DeMoor R. Combined Sodium Hypochlorite and $940 \mathrm{~nm}$ Diode Laser Treatment Against Mature E. Faecalis Biofilms invitro. Journal of Lasers in Medical Sciences. 2012;3(3):116.

21. Alfredo E, Souza-Gabriel AE, Silva SR, Sousa-Neto MD, Brugnera-Junior A, Silva-Sousa YT. Morphological alterations of radicular dentine pretreated with different irrigating solutions and irradiated with 980-nm diode laser. Microscopy Research and Technique. 2009;72(1):22-7.

22. Saraswathi MV, Ballal NV, Padinjaral I, Bhat S. Ultra morphological changes of root canal dentin induced by $940 \mathrm{~nm}$ diode laser: An in-vitro study. Saudi Endodontic Journal. 2012;2(3):131-5.

23. Siqueira JF, Rôças IN, Favieri A, Lima KC. Chemomechanical Reduction of the Bacterial Population in the Root Canal after Instrumentation and Irrigation with $1 \%, 2.5 \%$, and 5.25\% Sodium Hypochlorite. Journal of Endodontics. 2000;26(6):331-4.

24. Estrela C, Estrela CR, Barbin EL, Spanó JC, Marchesan MA, Pécora JD. Mechanism of action of sodium hypochlorite. Brazilian dental journal. 2002;13(2):113-7. 